\title{
PKM PEMBERDAYAAN KELOMPOK USAHA AL BARIK PENGOLAHAN TEPUNG KULIT PISANG DI DESA SIDOMULYO BAMBANGLIPURO BANTUL
}

\author{
Dwi Ernawati ${ }^{1}$, Titin Aryani ${ }^{2}$ \\ ${ }^{1,2}$ Fakultas 1lmu Kesehatan Universitas 'Aisyiyah Yogyakarta \\ E-mail: dwiernawati09@unisayogya.ac.id
}

\begin{abstract}
The success of a business requires many supporting factors, including health factors of business people and product innovation. So that special attention needs to be given to the success factors of a business, especially the health factors of business people and product innovation. Lately, businesses that are becoming a trending topic are food businesses. PKM partners are the Al-Barik business group, Sidomulyo Village, Bambanglipuro District, Bantul Regency, Jogjakarta which is located in the central area producing bananas in Bantul Regency. The problem of partners is don't have skill to process of waste, especially banana peels. The aim of PKM is to provide training in making banana peel flour, providing training in application of banana peel flour to cakes. The solution to be achieved is training in making banana peel flour and application on cakes. The method for carrying out training in make banana peel flour and application on cakes. Outputs to be produced are: 1) the creation of flour products from banana peel, 2) the creation of cake products made from banana peel flour.
\end{abstract}

Keywords - banana peel, innovation, flour

\begin{abstract}
Abstrak
Kesuksesan suatu usaha memerlukan banyak faktor pendukung, diantaranya faktor kesehatan pelaku usaha dan inovasi produk. Sehingga perlu diberikan perhatian khusus terkait faktor pendukung kesuksesan suatu usaha, khususnya faktor kesehatan pelaku usaha dan inovasi produk. Belakangan ini, usaha yang sedang menjadi trending topic adalah usaha bidang pangan. Mitra PKM adalah kelompok usaha Al-Barik, Desa Sidomulyo, Kecamatan Bambanglipuro, Kabupaten Bantul, Jogjakarta yang berada di daerah pusat penghasil pisang di Kabupaten Bantul. Permasalahan mitra adalah belum memiliki perhatian khusus terkait kesehatan pelaku usaha, K3, keamanan pangan, dan pengolahan limbah khususnya kulit pisang. Tujuan PKM adalah memberikan pelatihan pembuatan tepung kulit pisang, memberikan pelatihan aplikasi tepung kulit pisang pada kue. Solusi yang ingin dicapai adalah pelatihan pembuatan tepung kulit pisang dan aplikasi pada kue. Metode pelaksanaan pelaksanaan pelatihan pembuatan tepung kulit pisang dan aplikasi pada kue. Luaran yang akan dihasilkan adalah: 1) terciptanya produk tepung dari kulit pisang, 2) terciptanya produk kue berbahan dasar tepung kulit pisang.
\end{abstract}

Kata kunci-kulit pisang, inovasi, tepung

\section{PENDAHULUAN}

Kelompok usaha Al-Barik terlatak di wilayah Desa Sidomulyo. Wilayah desa Sidomulyo secara geografis berada di $421000 \mathrm{mt}-426000 \mathrm{mt}$; $9123000 \mathrm{mU}-9119000 \mathrm{mU}$. Dilihat dari topografinya ketinggian wilayah sidomulyo berada pada $30 \mathrm{~m}$ diatas permukaan laut, dengan curah hujan rata rata $20 \mathrm{~mm} /$ tahun serta suhu rata rata pertahun 30 derajat selcius dengan kelembaban $70 \%$ pertahun. Secara atministratif Desa Sidomulyo terletak di Kecamatan Bambanglipuro Kabupaten Bantul. Sebelah Timur berbatasan dengan Desa Panjangrejo Pundong, Sebelah Selatan berbatasan dengan Desa Tirto sari, sebelah timur berbatasan dengan Desa Sanden, dan sebelah utara berbatasan dengan Desa Mulyodadi Bambanglipuro. 
Desa Sidomulyo memiliki potensi lahan pekarangan 150.55 ha, Jumlah petani 1669 orang. Memiliki jalur alternatif yang sangat strategis yaitu jalur obyek wisata Pantai Parang Tritis dan Pantai Samas. Sidomulyo memiliki semboyan Intan berseri yang artinya Intelektual Inovatif berbasis Pada Usaha di Bidang Pertanian dan Peternakan, Perikanan, Industri Rumah Tangga sehingga menjadi Desa Yang Bersih sehat dan Asri. Sejak tahun 2004 Pemerintah Desa Sidomulyo mengalakkan masyarakat Sidomulyo untuk membudidayakan tanaman pisang raja. Buah pisang raja, merupakan buah pusaka. Pada bulan bulan tertentu buah Pisang raja bernilai ekonomis yang sanggat tinggi. Harga pisang raja persisir dapat mencapai 100 ribu /sisir. Pemerintah desa Sidomulyo melalui APBDES memfasilitasi modal Rp 500.000 untuk penanaman Pisang Raja di wilayah desa Sidomulyo.

Tugu Pisang Raja atau tugu selamat datang merupakan sarana yang dibangun pemerintah Desa Sidomulyo untuk mensosialisasikan kepada masyarakat bahwa Desa Sidomulyo merupakan desa penghasil pisang (bibit, buah dan aneka olahan). Pada Tahun 2007 diadakan program pembelajaran FEATI yaitu program peningkatan kemampuan petani melalui teknologi dan informasi pertanian yang dilaksanakan melalui kegiatan penyuluhan yang dikelola oleh petani. Pelaksana kegiatan dalam pembelajaran adalah UPFMA. UPFMA merupakan roh dari kegiatan FEATI. Dari kompilasi produk unggulan diperoleh bahwa komuditas yang paling utama adalah pisang. Dari rembug tani desa disepakati bahwa pembelajaran yang diangkat adalah pembelajaran Agribisnis Pisang. Dengan Tujuan utama dapa mendukung sidomulyo menjadi Banana Center (One Stop Shoping Banana Here) (Anonymous, 2012).

Kelompok usaha Al-Barik juga merupakan produk unggulan daerah, karena pisang merupakan ciri khas daerah Sidomulyo. Kelompok usaha ini terdiri dari 6 pengurus dan 12 anggota. Kelompok usaha AL-Barik memproduksi berbagai jenis keripik, terutama kripik pisang, dan dodol pisang. Kelompok usaha Al-Barik memerlukan banyak faktor pendukung, diantaranya faktor kesehatan pelaku usaha dan inovasi produk dalam mencapai kesuksesannya. Sehingga perlu diberikan perhatian khusus terkait faktor kesehatan pelaku usaha dan inovasi produk. Disamping masalah inovasi produk, kelompok usaha Al-Barik juga memiliki masalah produksi limbah, khususnya limbah kulit pisang, sehingga diperlukan pengolahan limbah kulit pisang menjadi produk berdayaguna seperti tepung kulit pisang.

Penelitian Aryani (2018), bahwa kulit pisang bisa dimanfaatkan untuk membuat tepung. Tepung pisang yang dibuat berasal dari kulit pisang raja. Tepung kulit pisang kemudian diaplikasikan sebagai tepung substituen pada pembuatan kue donat. Berdasarkan hasil uji organoleptik pada kue donat berbahan baku tepung kulit pisang, di dapatkan hasil bahwa rasa, warna, tekstur dan aroma yang dihasilkan pada tepung kulit pisang memiliki nilai rata-rata diatas 3 pada skala 4 dengan jumlah panelis 60 orang. Artinya bahwa kue donat berbahan dasar tepung kulit pisang memiliki daya terima yang baik untuk dikonsumsi. Pembuatan tepung kulit pisang pada akhirnya juga diharapkan berdampak pada menurunya impor tepung terigu di Indonesia.

Berdasarkan penelitian tersebut, maka program kemitraan masyarakat di Desa Sidomulyo Bambanglipuro Bantul, bertujuan untuk memanfaatkan limbah pembuatan keripik pisang dan olahan pisang lainnya agar berdayaguna dan menambah penghasilan bagi masyarakat setempat. Seperti diketahui bahwa di daerah tersebut adalah pusat pembuatan keripik pisang dan bonggol pisang, sehingga di daerah tersebut banyak kulit pisang yang tidak dimanfaatkan

\section{METODE}

Dalam kegiatan produksi makanan ringan khususnya yang berbahan dasar pisang, kelompok usaha Al-Barik menghasilkan limbah kulit pisang. Meskipun limbah kulit pisang merupakan limbah organik yang mudah terurai, tetapi keberadaannya cukup mengganggu estetika. Disamping menggangu estetika, sebenarnya kulit pisang dapat diolah menjadi produk yang lebih bermanfaat dan menambah nilai guna buah seperti tepung kulit pisang. Banyak dampak positif yang bisa diberikan ketika limbah kulit pisang dapat diolah, baik dampak langsung maupun tidak langsung. Dampak langsung bagi kelompok usaha Al-Barik adalah mengurangi jumlah limbah, menambah 
variasi produk, meningkatkan nilai guna buah, dan meningkatkan pendapatan perusahaan. Dampak tidak langsungnya adalah ketika Al-Barik dapat mengembangkan inovasi kulit pisang menjadi tepung, maka dapat mengurangi konsumsi tepung terigu bagi masyarakat sehingga impor tepung terigu dapat menurun.

Pembuatan tepung kulit pisang dimulai dengan cara memotong kulit pisang kecil-kecil dengan ukuran kurang lebih $1 \mathrm{~cm} \times 0,5 \mathrm{~cm}$ dengan pisau atau alat pengiris. Kemudian merendam kulit pisang dalam larutan natrium tiosulfat dan garam selama 1 jam, setelah itu ditiriskan. Proses pengolahan tepung kulit buah dimulai dari pengeringan kulit menggunakan oven $60^{\circ} \mathrm{C}$ sampai kulit menjadi benar-benar kering sehingga hasil akhir yang didapat berupa tepung yang kering. Setelah kering atau kadar air kurang lebih 14 persen, potongan kulit buah dapat digiling/dihancurkan dengan menggunakan hammer mill atau ditumbuk. Hasil penggilingan kemudian diayak. Tepung kulit buah yang lolos dari ayakan dikemas dalam kantong plastik (PKKP BKP, 2011).
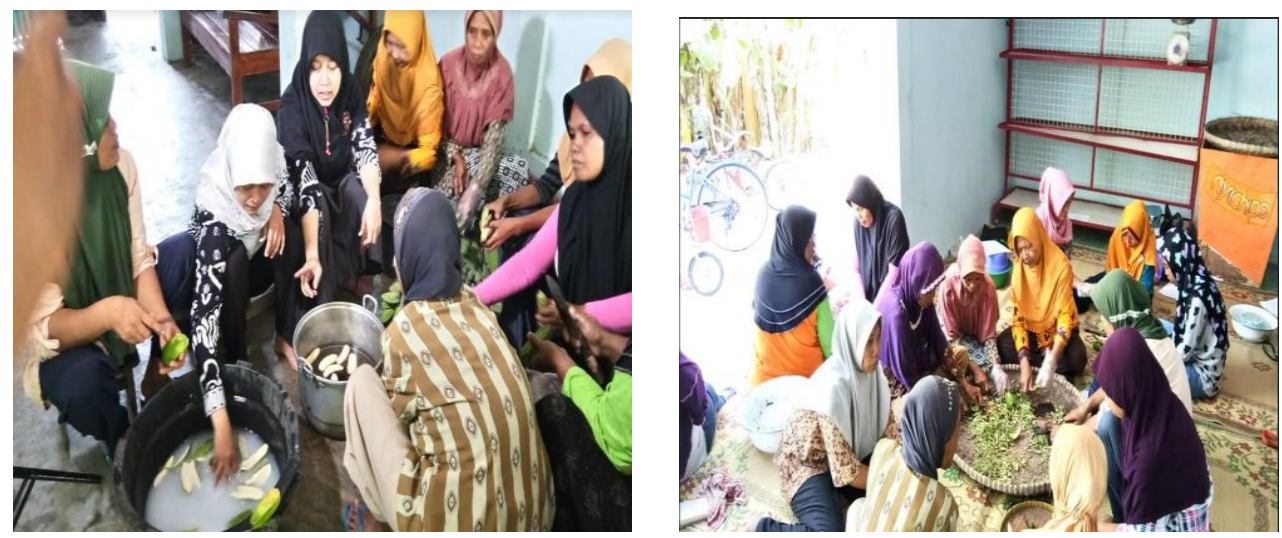

Gambar 1 Perendaman Kulit Pisang dan persiapan penjemuran kulit pisang

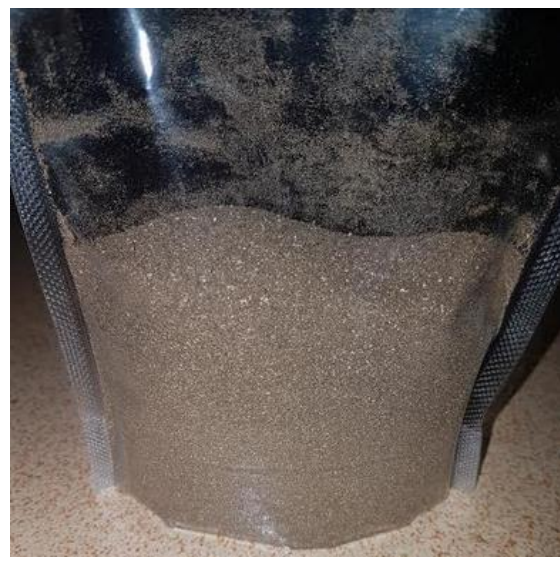

Gambar 2. Tepung Kulit Pisang
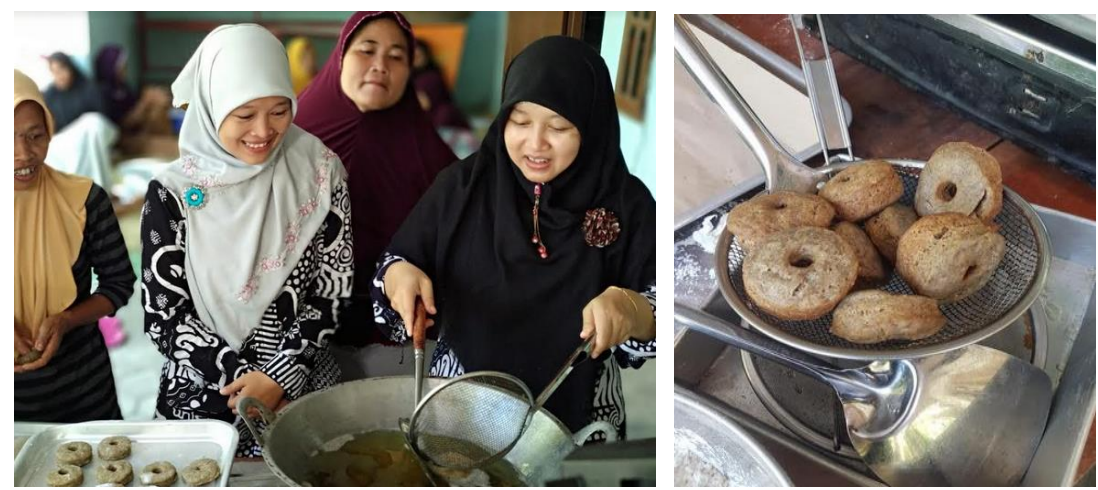

Gambar 3. Produk Tepung Kulit Pisang 


\section{HASIL DAN PEMBAHASAN}

Pengabdian kepada masyarakat yang telah dilakukan di Desa Sidomulyo Bambanglipuro Bantul, yaitu pengolahan limbah kulit pisang menjadi tepung, telah dilaksanakan. Kegiatan dilaksanakan di kelompok usaha AL Barik dengan peserta sebanyak 17 orang. Pelaksanaan kegiatan dilakukan dengan beberapa tahap yaitu memberikan pelatihan cara pengolahan kulit pisang untuk menghilangkan getahnya yaitu dengan merendam kulit pisang dalam air yang telah dicampur dengan soda kue, kemudian kulit pisang yang telah direndam di potong kecil kecil dan di keringkan. Proses pengeringan membutuhkan waktu 2 sampai 3 hari. Setalah tepung kulit pisang kering kemudain di giling lalu diayak agar menjadi lebut.

Pelatihan yang telah dilaksanakan meningkatkan keterampilan kelompok usaha AL Barik dalam mengolah limbah kulit pisang dan dapat memanfaat kan tepung kulit pisang untuk pembuatan kue donat. Kue donat yang di buat dari bahan tepung kulit pisang memiliki ciri khas dari rasa dan baunya. Tepung kulit pisang juga memiliki keunggulan lainnya yaitu mengandung zat gizi yang cukup tinggi terutama pada vitamin dan mineralnya, sehingga dapat dimanfaatkan sebagai bahan baku makanan dengan cara diolah menjadi tepung. Selain dimanfaatkansebagai bahan baku makanan, juga memperbaiki kandungan gizi bila diolah menjadi makanan.

Pada usia anak-anak hingga remaja merupakan usia penting untuk menabung kalsium dalam tulang. Pada usia remaja 75-85\% massa tulang yang akan dimiliki pada saat dewasa telah terbentuk. Proses pembentukan dan penimbunan massa tulang mencapai kepadatan maksimal pada usia 35 tahun. Semakin bertambah usia semakin sedikit jaringan tulang yang dibuat dan semakin banyak jaringan tulang yang dirombak sesudah usia 35 tahun, setiap tahunnya akan terjadi kehilangan massa tulang sebesar $0,5 \%$ dan setelah umur 50 tahun, jumlah kandungan kalsium dalam tubuh akan menyusut sebanyak 30\%. Kehilangan akan mencapai 50\% ketika mencapai umur 70 tahun dan seterusnya mengalami masalah kekurangan kalsium.

Hasil analisis kimia menunjukkan bahwa komposisi kulit pisang banyak mengandung air yaitu 68,90 persen dan karbohidrat (zat pati) sebesar 18,50 persen, sehingga dapat dimanfaatkan sebagai bahan baku pembuatan makanan. Karena kulit pisang mengandung zat patimaka kulit pisang dapat diolah menjadi tepung. Tepung ini dapat menggantikan atau mengurangi jumlah tepung yang biasa dipakai dalam pembuatan bahan makanan. Kulit pisang juga dapat dimanfaatkan dalam pembuatan jelly, cuka, dan sebagainya.

Dilihat dari perbandingan komposisi zat gizi tepung terigu dan kulit pisang, ternyata tepung terigumemiliki kandungan air $12 \mathrm{~g}$, karbohidrat 77,3 g, protein 8,9 g, lemak 1,3 g, kalsium $16 \mathrm{mg}$, fosfor $106 \mathrm{mg}$, besi $1,2 \mathrm{mg}$, vitamin B 0,12 mg, dan vitamin C 0 (DKBM, 1967). Sedangkan kulit pisang memiliki kandungan air 68,9 g, KH 18,5 g, Protein 0,32 g, Lemak 2,11 g, kalsium $715 \mathrm{mg}$, Fosfor $117 \mathrm{mg}$, besi 1,6 mg, vitamin B 0,12 mg, dan vitamin C 17,5 mg (Balai Penelitian dan Pengembangan Industri (1982) dalam Suprapti, 2005).

\section{KESIMPULAN}

Berdasarkan uraian kegiatan pengabdian kepada masyarakat di Desa Sidomoyo Bambanglipuro Bantul, dapat disimpulkan :

1. Limbah kulit pisang telah bisa dimanfaatkan

2. Bertambahnya keterampulan kelompok usaha Al Barik

3. Tepung kulit pisang dapat dipergunakan untuk membuat donat yang menghasilkan donat yang memiliki ciri khas dari rasa dan bau.

\section{SARAN}

Produk tepung kulit pisang yang telah di buat sebaiknya di daftar ke BPOM sehingga dapat di jual bebas. 


\section{UCAPAN TERIMA KASIH}

Penulis mengucapkan terima kasih kepada kemenristek DIKTI yang telah memberi dukungan financial terhadap pengabdian kepada masyarakat ini.

\section{DAFTAR PUSTAKA}

[1]Anonymous. 2012. Tentang Sidomulyo. Diakses tanggal 27 April 2018. http://up-fmasidomulyo.blogspot.co.id/2012/06/tentang-sidomulyo-w-ilayah-desa.html.

[2] T. Aryani, I. A. U. Mu'awanah, and A. Ba. Widyantara, "Karakteristik Fisik, Kandungan Gizi Tepung Kulit Pisang dan Perbandingannya terhadap Syarat Mutu Tepung Terigu Physical Characteristics, Nutritional Content of Banana Peel Flour and Its Comparison to Quality Requirement of Wheat Flour," JRST, vol. 2, no. 2, pp. 45-50, $2018 .$.

[3]PKKP BKP. 2011. Membuat Tepung dari Kulit Pisang. Pusat Penganekaragaman Konsumsi dan Kemanan Pangan Badan Ketahanan Pangan Republik Indonesia. Diakses pada 2 Mei 2018. http://pusat- pkkp.bkp.pertanian.go.id/berita-205-membuat-tepung-dari-kulitpisang.html.

[4] Suprapti LM. 2004. Keripik, Manisan Kering, dan Sirup Nangka. Yogyakarta (ID): Kanisius. 